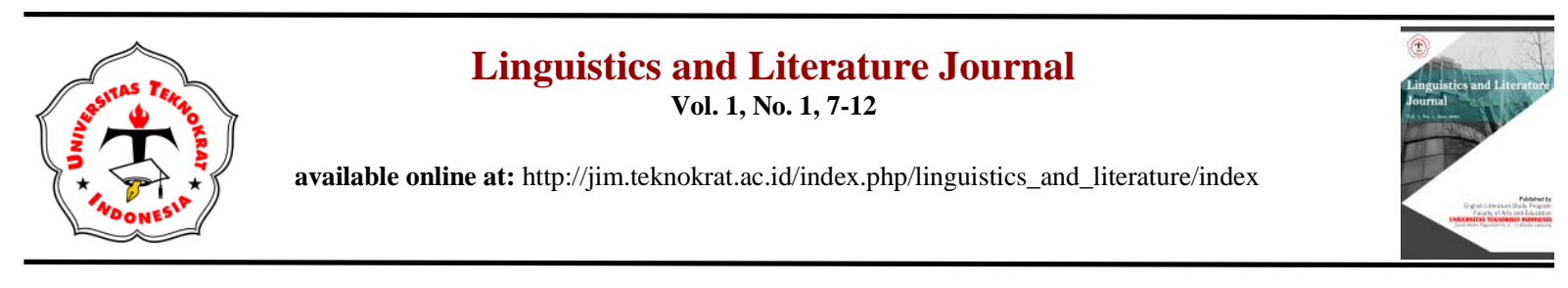

\title{
BLACK SKIN WHITE MASK: \\ HYBRID IDENTITY OF THE MAIN CHARACTER AS DEPICTED IN TAGORE'S THE HOME AND THE WORLD
}

\author{
Yanggi Mertania ${ }^{1}$, Dina Amelia ${ }^{2}$ \\ Universitas Teknokrat Indonesia ${ }^{1,2}$
}

yanggymertania@gmail.com ${ }^{1}$, amelia.dina@teknokrat.ac.id ${ }^{2}$

Received: (March 2020)

Accepted: (May 2020)

Published: (June 2020)

\begin{abstract}
This research paper describes the analysis of a literary work entitled The Home and The World by Rabindranath Tagore. This novel illustrates Tagore's inner battle about his ideas on the Western culture and on the revolution against Western culture when India was colonized by the British. These ideas portrayed in one of the main characters, Nikhil. Tagore represents himself as Nikhil, the hybrid, who is positioned between British and Indian cultures. The main purpose of this research is to describe the hybrid identity of Nikhil as one of the main characters in the novel within the context of colonized society and the Swadeshi movement. This research applied the post-colonial approach and hybrid identity theory by Homi. K. Bhabha and also applied the descriptive qualitative method to depict the problem by using the words. Library research was applied in the context of the data collecting process. The data are dialogues and narrations about the hybrid identity of Nikhil in The Home and The World novel. Based on the research conducted, it was concluded that the impact of British colonialism led to the formation of a hybrid identity process in Indian society. First, there was a hybrid identity of Nikhil as a part of the colonized society in education, lifestyle, culture, and social aspects. The second was the hybrid identity of Nikhil in the Swadeshi movement.
\end{abstract}

Keywords: Black skin white mask, colonialism, hybrid identity, post-colonial, rabindranath tagore, swadeshi movement, the home, and the world.

\section{INTRODUCTION}

In many works of literature, specifically those coming out of Africa, the Middle East, and the Indian subcontinent, we meet characters who are struggling with their identities in the wake of colonization, or the establishment of colonies in another nation. In India, the British had a colonial presence from the 1700s until finally, India gained its independence in 1947. The people of India, as well as the characters in Indian novels, must deal with the economic, political, and emotional effects that the British brought and left behind. In many cases, the literature stemming from these events is both emotional and political. Oberg in Setiawan states that there is a binary opposition between the Western and Eastern cultures (Lina \& Setiawan, 2017).

Rabindranath Tagore is also known as the Sobriquet Gurudev, he is a Bengali poet, Brahmo religionist, visual artist, playwright, novelist, and composer whose works reshaped Bengali literature and music in the late 19th and early 20th centuries. He becomes Asia's first Nobel laureate when he wins the 1913 Nobel Prize in Literature. The Home and The world is one of Tagore's literary works that brings him to win the Nobel Prize in Literature. This novel is adopted from colonialism by the British that happened in the early $19^{\text {th }}$ century in India. This novel illustrates the battle Tagore had with himself, between the ideas of Western culture and revolution against the Western culture. Colonialism not only influences the economic and political dynamics in India. Indirectly, colonialism also influences India in the term of culture by mixing the cultures of India and British which can be called as hybridity as stated by Bhabha that hybridity is the process by which the colonial governing authority undertakes to translate the identity of the colonized within a singular universal framework, (Meredith, 1998; Bhabha, 2012).

Hybrid identity theory is developed by Bhabha (2012) one of the significant post-colonial theorists. His book The Location of Culture has made prominent contributions to postcolonial criticism. Hybrid identity is presented in one of the main characters in The Home and The world novel named, Nikhil. The writers describe hybrid identity in Nikhil's character by borrowing the proverb "Black Skin White Mask" from a psychiatrist and intellectual from Martinique, Frantz Fanon. 
The significance of this research is to answer the problem of hybrid identity process occurs in post-colonial societies as a result of the superimposing of the colonizer's culture through economic, education, political and cultural control, or if settler invaders force indigenous peoples to assimilate the culture to India society in colonialism era reflected in one of the main characters in The Home and The world novel. This research is intended to provide insights about the effects of colonialism as the process of creating hybrid identity in the individuals that reflected through literary works especially for post-colonial literature that can be seen in Bengali, India. It is also expected that this research opens the reader's mind toward the hybrid identity process that can be happened in real-life since hybrid identity also occurs as a result of migration and globalization in the metropolitan communities, where complex cultural patterns form (Ashcroft et al, 2007).

\section{Post-Colonial Approach}

Literary works contain sources that would allow a reader or a researcher to explore colonial discourse because it is considered as media to reveal the author's ideologies (Woro Kasih, 2018).

The post-colonial approach is used to define, analyze, and understand literary work that coming from the colonialism era or setting in the post-colonialism era. The post-colonialism approach is particularly effective at helping the writers to see the connection among all the domains of experience such as psychological, ideological, social, political, and aesthetic in ways that show how inseparable these categories are in lived experience. Postcolonialism also affects in literature aspect which is shown by the literary works that produced in the postcolonial era, which most of them were created by colonial or colonized people.

As stated by Tyson (2006), as a subject matter, any analysis of postcolonial literary work, regardless of the theoretical framework used, might be called postcolonial criticism". It means that all literary works which are discussed about the condition of postcolonialism can be analyzed through postcolonial criticism.

\section{Hybridity and Hybrid Identity}

Hybrid identity has been discussed to elaborate on how the Chinese-American deal with hybrid identity to seek whether there is a cultural clash that happens between parents and children (Alitiyani, 2012). Another research reveals the idea of whether hybrid identity is the result of a multicultural society's upbringing as it is explained in the novel Ananda Devi (Krisnadreddy, 2010). Hybridity according to Bhabha is a problematic colonial representation and reverses the effect of the colonialist disavowal (of differences). The similar problem that also has been the main focus on Said's Orientalism, that there is a distinction between the "orient", in this case, the colonized people, and the "occident", the colonizers (Amelia, 2016). In other words, Bhabha's concept of hybridity gains currency in defining the vision of postcolonial theory that all cultures are influenced in each other and it cannot be separated. This leads to the creation of a hybrid identity as the effect of colonialism.

Homi K. Bhabha argues that the nature of colonial identity is not monolithic, but ambiguous or hybrid and to the interaction, even asymmetrical between the culture of the colonizer and the colonized. Therefore, identity, in the postcolonial discussion, is unstructured but there is a process of mixing in some interaction from the discrepancy between colonizer and colonized. According to Bhabha in Third Space in Postcolonial Discourse, hybridity is the process by which the colonial governing authority undertakes to translate the identity of the colonized within a singular universal framework but then fails to produce something familiar but new (Meredith, 1998; Bhabha, 2012). Bhabha seems to have explored more on the process of hybridity when colonizer takes over to interpret the identity of colonized society, in general, it leads the development of a new identity, a hybrid identity, as the mixture of the original and the new identity. Bhabha has developed his concept of hybridity from literary and cultural theory to describe the construction of culture and identity within the condition of colonial antagonism and inequity (Sayegh, 2008).

\section{The Colonized Society in India}

Colonialism as a process of forming a community in a new land necessarily meant un-forming or re-forming the community that existed there already and involved a wide range of practices including trade, plunder, negotiation, ware fare, and the most important genocide and enslavement to original inhabitant (Loomba, 2005). As a colonized society there is a wider range of Indian culture indicators received the impact of the colonial rule as education, literature, women, social class, and religion. A historian, A. L. Basham, argues that the administrative and judicial remains the same. In the education and industrial fields there has been expansion, but not suppression. British create the policy of education in India, there are two types of policies brought by the British. The first one was the elite religious schools. It mainly concerns with students whose main aim is to achieve a high level of education. The second type concerns with village boys. It is the local elementary school. The British administration, English education, and European literature brought to India a constellation of fresh ideas which constituted a challenge to the new intellects (Basham, 1975).

For the religion, Indian society was marked by a diversity of cultures in the subcontinent. This was also shown in religion. It is a place where Hinduism and Islam and later Christianity is considered as major religions. 
Religion played a significant role in the Indian's life as well as customs which were religious practices. Historian Geraldine Forbes argued that colonial officials agreed that religion was central to Indian life. Indian people were slaves to religion and sati (and many other customs) were religious practices (Forbes, 1996).

\section{The Swadeshi Movement}

The movements would have their assumptions about men's and women's roles which could either propel change or confirm continuity. Perceiving from the evolvement of British rules in the subcontinent, British people focus turned from "disinterestedly presiding over adjust regime westernizing India through economic and political reforms", Indian intellectual started a project to get their freedom which was known as "Swadeshi Movement".

Swadeshi means the goods of "our own". Indian goods the movement began in 1905 as described in historical economies of race and gender in Bengal. Swadeshi Movement was one of the major events in the history of India's independence movement from British imperialism which involved all of the people in India. There was a protest against the partition of Bengal by Lord Curzon. Swadeshi movement, in short, can be seen as an attempt to boycott British commodities as a protest against the British government.

\section{METHOD}

In analyzing the hybridity depicted in the main character, the method of research used by the writers is a descriptive qualitative and library study to support the writers' research. Qualitative means that the analysis based primarily on the constructivist perspective that involves individual experiences that have been historically or socially constructed (Aryangga \& Nurmaily, 2017). In other words, the data in the descriptive qualitative research are taken from the data source, in this case, The Home and The World by Rabindranath Tagore. As it is stated by Kardiansyah that the data in qualitative research are texts including narrations and dialogues (Kardiansyah, 2016). The processing of the data is started from reading the novel, highlight significant information based on the topic discussion, arrange and classify the data based on the approach and the theory, analyze, and evaluate carefully. Bogdan and Biklen (1982) in Lianasari and Samanik (2016) said that the data analysis is started by breaking down the data, choosing and organizing the data to be easily understood.

\section{FINDINGS AND DISCUSSION}

\section{Hybrid Identity of Nikhil as a part of the Colonized Society in India Nikhil's Hybrid Identity}

A hybrid identity can be seen in Nikhil's character. Nikhil is presented as an origin Indian man who is born in a rich family and makes him able to get an education and become an educated man. As stated in the quotation in the novel from Bimala's point of view "But my husband was modern. He was the first of the house to go through a college course and take his M.A. degree"(Tagore, 2011:4). Nikhil is presented differently by the author; he is presented as a person who is modern and well educated in that era. Nikhil implements his education into his life, starting from educated his wife, introduce the society in India to modern thought, and help the political movement to fight against colonialism by the British. Nikhil's hybrid identity can be seen by his action, behavior, lifestyle, and his modern thoughts describe in this novel. To analyze Nikhil's hybrid identity as a part of the colonized society in India, the writers differentiate the analysis into some aspects which are the hybrid identity of Nikhil in education, socialization, culture, and lifestyle.

\section{Nikhil Bimala's Perspectives \\ Education}

Education in India during the colonial era is still low, Indian is not aware of education until the British come. During the colonial era, the British introduce education to Indians by creating a policy of education (A.L. Basham, 1975). British obligate people to set education and the people in India starting to go to school to be educated. The educated people from colonized society are encouraged with the knowledge from both British and Indian cultures. Therefore, they are identified as identity-based on Bhabha. As quoted by Meredith states that the hybrid's potential is with their innate knowledge of transculturation (1998). Nikhil, the main character, is described by Bimala, his wife, as a modern man, because he is the first child in his family who manages to go to college, gets through a B.A. examination, and continues his study to Master Degree (Tagore, 2011: 4-5). "M.A. degree" indicates that the modern thought that Nikhil gets from British education is within the scope of humanities and social science. Taylor in Voicu explains that hybrid's potential is with their innate knowledge of 'transculturation' (2011), which means according to Bhabha, hybrid identity is a person who is potential with knowledge from 'transculturation' which means the mixture of the culture from British and India culture. 
In the novel, Nikhil's hybrid identity in education is not only affecting himself as a colonized society. Nikhil also tries to implement his modern thoughts that he gets from British education to others. One of them is his wife, Nikhil tries to implement his modern thoughts by introducing and educating his wife with British education as describes in the narration "The Chota Rani has got rid of all her fears by dint of English woman's teaching, ..." (Tagore, 2011: 260). From the quotation, Chota Rani refers to his wife Bimala, it states that Bimala can calmly face problems because of the teaching of her British teacher she gets. It indicates that Nikhil implements his modern thoughts by educating his wife. Nikhil is an educated person who introduces and educates his wife with modern standards of life which are education, modern lifestyle, and modern thoughts.

\section{Lifestyle}

Nikhil often buys modern fashion clothes for his wife who is originally an India (Tagore, 2011). Nikhil also likes to buy modern clothes for his family. It is also stated that his grandmother does not like the modern dresses he buys and calls it an absurd hobby. In Indian society, both men and women usually wear their traditional clothes. For man is Kurta and for women is Sari. But, Nikhil has a different taste in styling his wife and does not follow the tradition of India in style (Tagore, 2011). Nikhil's hybrid identity in his lifestyle also can be seen from Nikhil taste in decorating his home as stated in the narration from Bimala's point of view "My husband had filled more than a hundred and twenty percent of the house with the twentieth century, against her taste; but she had borne it uncomplaining" (Tagore, 2011: 13).

Nikhil often interacts with European and invites them to his house when India tries to fight against British colonialism. His wife, Bimala shows that actually, she dislikes Nikhil's habit and lifestyle by sneaking up into Nikhil's room and change the vase made from copper into crystal vase made from Europe to insult Nikhil's about his habit (Tagore, 2011).

\section{Culture}

Nikhil hybrid identity makes Nikhil oppose patriarchy culture by educating and introducing his wife with modern thoughts as describes in Nikhil's hybrid identity in the education aspect. Nikhil asks his wife to see the world since these actions are not allowed based on Indian culture. Based on India's culture, after marriage women are not allowed to go out of purdah and only stay in the home doing housework and take care of children. Nikhil tries to overstepping India's culture by asking his wife to go out of purdah and see the outside world. Nikhil thinks that a woman has the same right as a man (Tagore, 2011). Nikhil states that Bimala is not born only to stay home and does household but, Bimala has the same chance as him to be educated and got a lot of experiences as men can do. Nikhil wants Bimala to see the world clearly, without the shadow of cultures that influence her perspective in life (Tagore, 2011).

Nikhil is not only opposing patriarchy culture. He also tries to oppose Indian funeral traditions that sometimes only burdening poor people. Panchu is one of the poor workers who work in Nikhil's traditional market. The quotation stated that Panchu's wife passes away and he needs to conduct a funeral and purification ceremony that must be done by Indian society based on their culture and traditions. Pancu's neighbors force him to pay a lot of money to conduct this ceremony when he is grieving and has no money. Nikhil tries to reject this tradition by asking Panchu not to follow the ritual (Tagore, 2011). Nikhil's action shows that Nikhil rejects his origin culture by questioning the rightness of the cultures and traditions itself. The new space of cultural meaning or hybrid identity blurring the old culture creating confusion in the identity or culture makes them questioning the rightness of the cultures. Hybrid identity emerges when identity challenges the rightness of the culture or identity (Meredith, 1998).

\section{Social}

Hybrid identity is the result of the intensity of colonizers and the colonized people in the term of crosscultural exchange. As stated by Aschoft that hybridity refers to the creation of new transcultural forms within the contact zone produced by colonialization. (Aschroft, 2007). Nikhil tries to implement his knowledge to Indian society by finding innovation regarding food and drinks production are taken from the plants around their environment. Even though his efforts are not successful, Nikhil does not give up and still tries to implement his knowledge to people in India as stated in the narration "My husband list of charities was a long one. He would assist to the bitter end of utter failure anyone who wanted to invent a new loom or rice the husking machine." (Tagore, 2011: 19). Nikhil is trying to develop his region by looking for anyone who can build a new loom or rice husking machine. Nikhil tries to teach people the ideas of thrift and starts a small bank at that time. Even though his effort only brings him to bankruptcy because the interest he offers to society is too high (Tagore, 2011). 


\section{Hybrid Identity of Nikhil in the Swadeshi Movement Nikhil and Swadeshi Movement}

Tagore assesses that swadeshi is changing becomes an elitist movement that only profits the higher class of the society and damages the poor. This disappointment leads the author of this novel to concentrate the attention on the battle he has with himself between the idea of western culture and revolution against western culture makes Tagore represent himself as one of the main characters in this novel named Nikhil. Nikhil character is positioned in the middle between British and India makes Nikhil can be classified as a hybrid identity. As stated in the quotation: The hybrid identity is positioned within this third space, as 'lubricant' in the conjunction of cultures (Meredith, 1998). Nikhil tries to implement his knowledge in business into the swadeshi movement by buys Indian mill yarn and starts to produce origin Indian fabrics. Nikhil also tries to support the industries of India by imported Indian mill-made yarn to be sold in his market in Suksar and other markets. But, no one is interested to buy Indianmade yarns because of their bad quality and expensive price (Tagore, 2011).

Nikhil sees this problem from the other perspective and realizes that there is something wrong with this movement. Bhabha posits hybridity as such a form of liminal or in-between space, where the 'cutting edge of translation and negotiation' occurs and which he terms the third space (2012). In other words, Bhabha explores, in hybridity, usually the old identities or origin identities do not simply disappear, although new cultural identities will strongly influence the old identity. Here, then what Bhaba calls as an ambiguity of identity that takes someone "in-between" or "in the middle" position.

\section{CONCLUSION}

Indirectly the interaction between colonizers and colonized in colonialism create the influence through the society especially colonized society. The colonized society starts to adopt modern thought brought by the colonizer. It leads to the creation of a new identity in the society who is posited in the middle between colonizers and colonized cultures. This identity is called a hybrid identity that shows in one of the main characters in The Home and The World novel named Nikhil. Nikhil's character is present as a nobleman from India who is educated by British education makes his way of thinking and action is like a British. Nikhil's hybrid identity can be seen as a part of the colonized society in some aspects such as education, lifestyle, culture, and society. Nikhil's hybrid identity also can be seen in the swadeshi movement as one of the major histories in this novel. Swadeshi movement is a political movement that uses to wake up the spirit of freedom struggle in India to fight against British colonialism by boycotting British goods for support origin India's industries.

The influence of British during the colonialism in India as described the novel gives positive influence in Nikhil's character it can be seen in Nikhil's actions as a colonized society of India starting from educated his wife, styling his wife with modern dresses of British woman, socialize with European, overstepping the culture of India, implements his knowledge to develops society in India and using his British education to fight against British education through swadeshi movement indicates that Nikhil is a hybrid identity who posit in the middle between British and India cultures. To describe Nikhil's hybrid identity, the writers give proverb that reflected Nikhil's hybrid identity as stated in the title of this research "Black Skin White Mask" this proverb borrowed from Franz Fanon. Black Skin White Mask here describes that Nikhil as origin Indian "Black Skin" who is colonized by British is adopted colonizers cultures into his life makes his way of thinking, lifestyle, and actions are like British as colonizers liken Nikhil wearing "White Mask" to look equal with the colonizer. In other words, Black Skin White Mask is representing Nikhil as a hybrid identity describes in the literary work entitled The Home and The World written by Rabindranath Tagore.

\section{REFERENCES}

Alitiyani, Edita Rina. (2012). Hybrid Identity and Cultural Clash as Reflected in Chinese-American Mothers and Daughters in Amy Tan's The Joy Luck Club. Yogyakarta: UNY.

Amelia, Dina. (2016). Indonesian literature's position in world literature. Teknosastik: Jurnal Bahasa dan Sastra, $14(2), 1-5$.

Aryangga, Afri \& Nurmaily, Ely. (2017). Women's power and stereotype denial in Pocahontas movie. Teknosastik: Jurnal Bahasa dan Sastra, 15(1), 46-58.

Ashcroft et al. (2007). The Post-colonial Studies The Key Concepts, Second Edition. New York: Routledge.

Bhabha, Homi K. (2012). The Location of Culture. London: Routledge. 
Basham, A. L. (1975). A Cultural History of India. Oxford: Oxford University Press.

Forbes, Geraldine. (1996). The New Cambridge History of India IV.2: Women in Modern India. Cambridge Histories online: Cambridge University Press.

Kardiansyah, M. Yuseano. (2016). The index of hero's power and nobility in Shakespearean tragedy drama: A semiotic study. Teknosastik: Jurnal Bahasa dan Sastra, 14(2), 1-17.

Kistnadreddy. (2010). Hybridity in The Novels of Ananda Devi. The University of Nottingham.

Meredith, Paul. (1998). Hybridity in the $3^{\text {rd }}$ Space: Re-thinking Bi-Cultural Politics in Aotearoa/New Zealand. The University of Waikato.

Lianasari, Fita \& Samanik. (2016). Antimatter technology: The bridge between science and religion toward universe creation theory illustrated in Dan Brown's Angels and Demons. Teknosastik: Jurnal Bahasa dan Sastra, 14(2), 18-27.

Lina, Desma \& Setiawan, Dwi Budi. (2017). An analysis of culture shock from west to east as seen in Reilly's The Tournament. Teknosastik: Jurnal Bahasa dan Sastra, 15(1), 14-20.

Loomba, Ania. (2002). Colonialism/Post-colonialism. London: Routledge.

Lois, Tyson. (2006). Critical Theory Today: A User-Friendly Guide. New York: Routledge.

Sayegh, Pascal-Yan. (2008). Cultural Hybridity and Modern Binaries: Overcoming the Opposition Between Identity and Otherness? Halshs-00610753.

Tagore, Rabindranath. (2011). The Home and The World. Digireads.com. Publishing.

Voicu, Cristina-Georgiana. (2011). Crossing borders of hybridity beyond marginality and identity. The University of Bucharest Review, 1(1), 171-193.

Woro Kasih, E. Ngestirosa. (2018). Redefining hybridity of Chicano literature in Jimenez's fictions. International Journal of Diaspora \& Cultural Criticism, 8(2), 294-319. 